\title{
Komunikasi Dakwah Gus Miftah Di Lokalisasi Pasar Kembang Yogyakarta
}

\author{
Muslimin Ritonga ${ }^{1}$, Dewi Sartina ${ }^{2}$ \\ ${ }^{1}$ UIN Sunan Kalijaga Yogyakarta, UIN Raden Fatah Palembang \\ e-mail: ${ }^{1}$ musliminritonga@ @mail.com, ${ }^{2}$ sartinadewi4796@gmail.com
}

\begin{abstract}
Da'wah communication is a da'wah activity communicated by the Da'wah communicator to the Da'wah communicant that aims to communicate religious values, and can implement these values in daily actions and behavior. But in reality, the process of delivering da'wah is not an easy activity to carry, many problems and obstacles faced by preachers when carrying out missionary mission. Thus, a mature preacher is needed in carrying out and delivering the message of preaching to the wider community. Like the preaching carried out by Gus Miftah in the Localization of Yogyakarta Flower Market. Preaching in the black area like this, of course, a preacher must have the mentality, courage, readiness and have the right approach, strategy and method so that preaching can be accepted in the middle of the black area
\end{abstract}

Key Words: Da'wah Comminication, Strategic Da'wah, Localization Of The Flower Market

\begin{abstract}
Abstrak
Komunikasi dakwah merupakan suatu aktivitas dakwah yang dikomunikasikan oleh komunikator dakwah kepada komunikan dakwah y ang bertujuan untuk mengkomunikasikan nilai-nilai agama, serta dapat mengimplementasikan nilai-nilai tersebut pada tindakan dan perilaku seharihari. Namun realitasnya, proses penyampaian dakwah bukanlah suatu kegiatan yang mudah untuk diemban, banyak problem dan hambatan yang dihadapi oleh pendakwah saat melakukan misi dakwah. Dengan demikian, dibutuhkan pendakwah yang matang dalam menyampaikan pesan dakwah kepada masyarakat luas. Seperti halnya dakwah yang dilakukan oleh Gus Miftah di Lokalisasi Pasar Kembang Yogyakarta. Berdakwah di kawasan hitam seperti ini tentunya seorang da'i harus memiliki keberanian, kesiapan serta memiliki pendekatan dan strategi yang jitu agar dakwah dapat diterima ditengah-tengah kawasan hitam tersebut.
\end{abstract}




\section{Kata Kunci: Komunikasi Dakwah, Strategis Dakwah, Lokalisasi Pasar Kembang}

\section{A. Pendahuluan}

Dakwah dan prostitusi merupakan dua hal yang berbeda secara diametral. Dakwah secara etimologi dapat diartikan sebagai ajakan untuk mematuhi apa yang dikehendaki oleh Yang Maha Kuasa. Sementara prostitusi dapat diartikan sebagai ajakan penyerahan diri untuk melakukan aktifitas seksual dengan mendapatkan upah. Meskipun kata kerja yang ada dalam kata prostitusi dan dakwah adalah ajakan namun hakikatnya memiliki arah yang berlawanan. Satu kata mengajak kepada sesuatu yang luhur, sementara yang lain mengajak kepada sesuatu yang rendah dan hina (Maryono, Menakar Efektivitas Dakwah di Lokalisasi Pasar Kembang Yogyakarta Dengan Pendekatan Model Matematika, vol. 18 no 1 2018: 154).

Menurut Samsul Munir, dalam menatap problematika dakwah menuntut adanya upaya intensif untuk menelaah dan menanggapi gejala-gejala aktual yang akan dan telah terjadi. Dengan cara ini persoalan keagamaan yang berkaitan dengan realitas objektif keumatan dapat dihampiri dan direkonstruksi sesuai dengan tatanan ideal Islam. Tugas berat ini telah dibebankan pada dakwah Islam yang tentunya sangat membutuhkan kecermatan, kearifan, dan kejelasan bidang garap serta sandaran konseptual yang mapan (Samsul Munir, 2008: 152).

Menurut Syamsuddin, problematika dan masalah-masalah yang dakwah yang kerap terjadi adalah kurangnya kesiapan dan kemampuan membangun komunikasi yang baik dan intensif serta kurangnya kesiapan dan kemauan untuk memahami dan menerapkan kaidah-kaidah ilmiah dan amaliah dalam menyikapi perbedaan (Syamsuddin, 2016: 148). Saat ini, prostitusi telah menjadi masalah besar di berbagai negara termasuk di Indonesia. Penyebaran prostitusi Lokalisasi di Indonesia hingga tahun 2014 berjumlah 161 tempat dan baru 23 yang ditutup (per 20 Juni 2014, "Penyebaran Lokalisasi di Indonesia 2014 dalam 
http://www.detiknews.com. diakses 5 Juni 2020).

Salah satunya tempat prostitusi di Indonesia yang cukup terkenal adalah Lokalisasi Pasar Kembang yang bermarkas di jantung kota Yogyakarta. Tempat tersebut memiliki posisi sangat strategis dari jangkauan para pengunjung dan pusat perdagangan, sebab mempunyai akses yang mudah untuk dicapai. Ini merupakan faktor yang menyebabkan semakin mudah untuk melakukan transaksi dalam kawasan hitam ini.

Dalam hal ini, aktivitas transaksi di kawasan hitam sulit untuk dilenyapkan, selagi masih berhubungan dengan problem-problem perekonomian dan kesenjangan pangan dan sosial. Untuk menghilangkan praktek-praktek di kawasan hitam tersebut, perlu adanya spirit dalam membangun komunikasi dengan para pendakwah, pejabat setempat, dan tentunya dorongan dari masyarakat sekitar. Oleh karena itu, perlu peran dakwah dalam mengatasi praktek di kawasan hitam tersebut, dengan cara menggunakan pendekatan-pendekatan, diantaranya pendekatan dakwah.

Sehubungan dengan itu, di Yogyakarta akhir-akhir ini muncul seorang tokoh pendakwah yang fenomenal yaitu Gus Miftah. Dia merupakan da'i yang menjelajah berbagai kalangan mulai dari lingkungan elit sampai kelingkungan pinggiran. Gerakan dakwah Gus Miftah dinilai unik dan diferensial dengan beberapa da'i yang lain di Indoensia, karena Gus Miftah bukan hanya berdakwah di kalangan santri dan masyarakat muslim secara normal, tetapi tempat-tempat yang dianggap krusial dan kawasan hitam seperti prostitusi lokalisasi (wawancara dengan Gus Wahyu selaku sekretaris pengurus Pondok Pesantren Ora Aji, 25 Mei 2020).

Kekhasan yang dimiliki Gus Miftah dalam berdakwah adalah keberaniannya melakukan dakwah di tempat-tempat kawasan "hitam" yang tak jamak, seperti Lokalisasi yang selama ini relatif tak pernah dipikirkan sebagai target dakwah. Tentu, apa yang dilakukan Gus Miftah tersebut bukanlah hal yang 
mudah. Namun, dengan kelebihan yang dimilikinya mampu mengatasi halangan dan resiko yang ada (wawancara dengan Agus Joko Mulyono selaku kepala kelurahan Sosromenduran, 2 Juni 2020).

Secara kultural, dakwah Gus Miftah di Lokalisasi masih memantik reaksi dari berbagai kalangan. Perspektif sosial masih memberikan stigma negatif kepada para penghuni kawasan hitam. Selain itu, resistensi para pelaku kegiatan di kawasan tersebut yang tak jarang justru terganggu dengan upaya-upaya dakwah yang bisa membawa dampak terganggunya kegiatan usaha mereka (wawancara dengan Sarjono selaku ketua RW 03 Kampung Sosrowijayan Kulon, 2 Juni 2020). Oleh sebab itu, paparan di atas menjadi realitas menarik bagi peneliti. Kajian tentang bagaimana komunikasi dakwah Gus Miftah dalam menghadapi masalah dan kendala yang menjadi hal penting saat melakukan proses penyampaian dakwah di Lokalisasi Pasar Kembang Yogyakarta.

\section{B. Metode Penelitian}

Penelitian ini menggunakan metode penelitian deskriptif kualitatif dan teknik pengumpulan data diperoleh berdasarkan hasil observasi, wawancara dan studi pustaka.

\section{Hasil dan Pembahasan \\ C.1 Komunikasi Dakwah}

Menurut Ahmad Mubarak dalam buku Psikologi Dakwah mengungkapkan bahwa kegiatan dakwah adalah kegiatan komunikasi, dimana da'i mengkomunikasikan pesan dakwah kepada mad'u, baik secara perseorangan maupun kelompok. Secara teknis, dakwah adalah komunikasi da'i (komunikator) dan mad'u (komunikan). Semua hukum yang berlaku dalam ilmu komunikasi berlaku juga dalam dakwah, hambatan komunikasi adalah hambatan dakwah, dan bagaimana mengungkapkan apa yang tersembunyi dibalik perilaku manusia 
dakwah sama juga dengan apa yang harus dikerjakan pada manusia komunikan (Wahyu Ilahi, 2013: 24).

Dakwah adalah praktek komunikasi, namun tidak semua praktek komunikasi dapat disebut sebagai dakwah. Dakwah merupakan salah satu aktivitas komunikasi, karena dalam dakwah terjadi transmisi informasi (pesan) dari komunikator (da'i) kepada komunikan (mad'u) melalui berbagai media. Seluruh unsur proses komunikasi termuat dalam berbagai praktek dakwah. Dengan demikian, jelas bahwa aktivitas dakwah merupakan praktek komunikasi (Waryani Fajar dan M. Mahfud, 2012: 11). Jadi, komunikasi dakwah merupakan kegiatan mengkomunikasikan materi dakwah atau pesan dakwah kepada komunikan dakwah (mad'u) dengan tujuan agar mendapat pengaruh kebaikan.

\section{C.2 Langkah Strategis Komunikasi Dakwah Gus Miftah di Lokalisasi Pasar Kembang Yogyakarta}

Untuk mengatasi hambatan dan problem komunikasi dakwah, langkahlangkah yang dilakukan Gus Miftah yaitu:

\section{a. Membangun Kredibilitas di Mata Masyarakat Pasar Kembang}

Kredibilitas merupakan kepribadian baik yang dimiliki oleh seorang da'i dalam melakukan suatu aktivitas. Dalam membangun kepercayaan di mata masyarakat kepada seorang da'i tentu harus memiliki kepribadian kredibiltas yang cakap. Menurut Hovland dan Wiss menjelaskan bahwa kredibilitas atau ethos itu ialah yang memiliki dua komponen yakni expertise yaitu keahlian tentang topik yang dibicarakan, dan trust worthiness yaitu dapat dipercaya, karena cerdas, berakhlak mulia, kepribadian yang bersahabat, tahu banyak, berpengalaman dan terlatih (Anwar Arifin, 2011: 237).

Dalam membangun kredibiltas atau kepercayaan di mata masyarakat seorang da'i harus memiliki kepribadian yang baik, karena akan berdampak bagi sasaran dakwah yang dituju. Sebagaimana yang diteladankan oleh Gus Miftah 
dalam berdakwah di Lokalisasi Pasar Kembang. Hal ini, penulis akan menjelaskan kredibilitas kepribadian yang menonjol pada Gus Miftah dalam membangun trust (kepercayaan) di mata masyarakat Lokalisasi Pasar Kembang yang nantinya akan berpengaruh sukses dan diterima nya dakwah Gus Miftah di kawasan tersebut.

\section{1) Kharismatik}

Kharismatik merupakan segala kepribadian luhur yang melekat pada seorang da'i, yang memiliki pesona atau daya tarik tersendiri karena mampu mengendalikan sikap, tingkah laku dan perilaku publik.

Beberapa kharismatik yang dimiliki oleh Gus Miftah dalam membangun kepercayaan di mata masyarakat Pasar Kembang (wawancara dengan Gus Aris selaku Pembina Pondok Pesantren Ora Aji, 6 Juni 2020).

a) Gus Miftah memiliki empati yang tinggi. Hal itu terbukti dengan kepedulian beliau kepada mereka (PSK, mucikari dan preman) dan menjadikannya seperti keluarga sendiri.

b) Kemampuan Gus Miftah dalam membangun komunikasi yang baik. Hal ini terbukti bagaimana keberanian mendatangi dan mengambil resiko dalam berdakwah di Lokalisasi.

c) Gus Miftah memiliki sikap amanah (terpercaya). Hal itu terbukti beliau sudah 14 tahun lebih berdakwah di Lokalisasi Pasar Kembang tentu karena adanya kepercayaan dari masyarakat Lokalisasi.

d) Gus Miftah memang memiliki kemampuan dalam bidang ini. Artinya dapat menempatkan sesuatu pada porsinya masing-masing.

e) Gus Miftah seorang da'i yang inovatif yakni selalu bisa memperbaharui dan menyesuaikan dengan kondisi dan situasi Lokalisasi Pasar Kembang.

Jadi, berdasarkan pemaparan di atas bahwa dalam membangun kredibilitas di tengah masyarakat Pasar Kembang, Gus Miftah menggunakan jiwa kharismatik yang beliau miliki. Dengan karakter dan moralitas terpuji yang dimiliki Gus 
Miftah dapat membangun kepercayaan masyarakat Pasar Kembang, sehingga beliau dan dakwah mudah diterima.

2) Ikhlas

Ikhlas merupakan niat seseorang yang hanya mengharap ridha Allah semata saat melakukan suatu aktivitas, dan tidak riya dalam beramal. Sikap keihklasan inilah salah satu tiang utama agar dakwah yang disampaikan dapat berjalan dan mudah diterima oleh objek dakwah. Sebagaimana dakwah yang dilakukan oleh Gus Miftah di Lokalisasi Pasar Kembang, beliau berdakwah di Pasar Kembang sudah 14 tahun tanpa ada bayaran. Meskipun jadwal beliau penuh, beliau selalu menyempatkan waktu luang minimal sekali sebulan untuk menyampaikan dakwah di Lokalisasi Pasar Kembang. Selain itu, Gus Miftah juga menerima mereka (PSK, mucikari, dsn preman) yang ingin menimba ilmu dan tinggal di Pondok Pesantren Ora dengan gratis tanpa ada biaya yang dipungut satupun.

3) Istiqomah

Istiqomah merupakan sikap konsistensi seorang da'i dalam melakukan aktivitas dakwah, baik yang baru dilakukan maupun yang sudah berjalan sekian lama. Dalam mempertahankan sikap istiqomah, Gus Miftah berkeyakinan sikap istiqomah akan melahirkan sikap optimisme. Gus Miftah optimis, bahwa dakwah yang disampaikan akan dapat berpengaruh kepada mereka. Gus Miftah berdakwah di Lokalisasi Pasar Kembang sudah bertahun-tahun, dan sampai sekarang beliau masih tetap istiqomah berdakwah disana. Seperti penuturan dari Gus Wahyu.

"Salah satu suksesnya dakwah abah, karena abah tetap istiqomah berdakwah di Sarkem, mereka itu sperti beterai hp, baterai hp akan lobet jikalau tidak di cas, sama halnya seperti mereka, mereka akan kembali lagi ke aktivitas mereka yang dulu jikalau dakwah berhenti, kan iman seorang begitu juga, kadang naik dan kadang turun" (wawancara dengan Gus Wahyu sekretaris pengurus Pondok Pesantren Ora Aji, 20 Juni 2020).

Dari penjalasan tersebut, bahwa Gus Miftah berdakwah di Lokalisasi Pasar Kembang memiliki sikap istiqomah. Hal ini terlihat bagaimana beliau bisa 
mempertahankan sikap konsistensinya, sikap teguh pendirian dari tawaran kerja yang menggiurkan, serta hambatan dan tantangan lainnya. Gus Miftah berdakwah di Pasar Kembang dengan totalitas, dengan dakwah totalitas akan menambah sikap optimism bahwa dakwah akan bisa disampaikan kepada mereka.

4) Memberikan Fasilitas Dakwah

Menurut Abdul Chalik, tugas seorang da'i adalah menfasilitasi masyarakat untuk dapat mengeluarkan potensi dan kemauan yang masih tersembunyi untuk kemudian menampakkannya. Dengan berkembang dan munculnya potensi tersebut secara tidak langsung dapat memicu kehadiran rasa percaya diri dalam diri mad'u (Abdul Chalik dan Muttaqin Habibullah, 2018: 169)

Berdakwah di era ini, seorang da'i bukan lagi hanya berdakwah di atas mimbar, diruang-ruang publik, akan tetapi juga berdakwah dengan memberikan fasilitas serta berdiskusi bareng dengan mad'u. Hal tersebut dilakukan, untuk mengetahui dan memecahkan problem yang mereka hadapi. Bagi mereka, nasehat dan pesan dakwah yang disampaikan bukan solusi yang riil atas kebutuhan mereka, sehingga menjadikan mereka tetap melakukan aktivitas tersebut karena desakan ekonomi.

Sebagaimana Gus Miftah sampaikan, bahwa untuk memenuhi sedikit kebutuhan dan sarana mereka, Gus Miftah mengeluarkan dana pribadinya untuk keperluan mereka. Seperti yang beliau sampaikan;

"Begini mas, dakwah butuh pengorbanan, saya bilang sama mereka gak usah hitung-hitungan, bila perlu komsumsi yang bawain saya, termasuk di Sarkem itu setiap kali pengajian saya bawa 200 sampai 300 ratus nasi kotak untuk mereka makan. Mereka butuh mukena saya fasilitasi, mereka butuh sajadah saya fasilitasi dan mereka butuh Al-Qur'an saya beli untuk mereka". (wawancara dengan Gus Miftah selaku pendiri Pondok Pesantren Ora Aji, 20 Juni 2020).

Dari wawancara tersebut, Gus Miftah melakukan hal demikian bukan karena ujub (bangga diri) tetapi karena semangat fastabiqul khairot (berlomba- 
lomba dalam mencari kebaikan atau pahala), dan beliau berkeyakinan bahwa di dalam rezeki manusia terdapat hak-hak orang lain juga. Oleh karena itu, ini menjadi spirit untuk melakukan dakwah di Lokalisasi Pasar Kembang.

\section{b. Mengenal Kondisi Komunikan Dakwah}

Mad'u adalah manusia yang menjadi sasaran dakwah, baik secara individu, kelompok, baik yang beragama Islam maupun tidak, dengan kata lain manusia secara keseluruhan (Wahyu Ilahi, 2013: 19). Dalam hal ini, yang menjadi sasaran dakwah Gus Miftah adalah PSK, preman, mucikari yang tergabung dalam aktivitas prostitusi Lokalisasi Pasar Kembang.

Untuk dekat dengan mad'u, Gus Miftah melakukan pendekatan melalui penampilan. Gus Miftah berusaha menyesuaikan diri dengan berpakaian seperti yang mereka gunakan, misalnya dengan berpakai kaos, blangkon, dan rambut yang menyerupai preman. Penampilan yang seperti ini tidak lazim digunakan oleh para penda'i pada umumnya. Dengan berpenampilan seperti ini, Gus Miftah menjadi lebih dekat dengan mad'u, karena mereka merasa setara dan tidak ada perbedaan dengan Gus Miftah, sehingga dakwah beliau lebih mudah diterima oleh mereka (PSK, mucikari, dan preman).

Selain penampilan, Gus Miftah juga memilih materi yang sesuai dan mudah diterima oleh mereka. Gus Miftah memilih materi yang bersifat umum karena tidak semua latar belakang mereka berasal dari agama Islam. Materi yang bersifat umum lebih mudah diterima oleh semua golongan baik dari yang Islam maupun non Islam. Selanjutnya, pendekatan yang digunakan oleh Gus Miftah adalah melalui pendekatan ekonomi. Pendekatan yang digunakan salah satunya dengan memberikan bantuan berupa uang dan memberikan relasi pekerjaan. Melalui pendekatan ini Gus Miftah berusaha membantu mereka dengan memberikan pekerjaan yang lebih baik, dengan begitu mereka dapat meninggalkan pekerjaannya yang lama.

\section{c. Membangun Kerja Sama}

Faktor pendukung dalam berdakwah sangat dibutuhkan sekali, sebab 
seorang da'i dituntut bukan hanya mampu penyampaikan dakwah, tapi juga cermat dalam membangun menjalin komunikasi dengan faktor pendukung tersebut. Adapun faktor pendukung pada umumnya adalah membangun komunikasi dengan lembaga-lembaga, organisasi dan lainnya. Hal ini, tentu akan menambah keefektifan dalam proses penyampain misi dakwah. Sebagaimana yang dilakukan oleh Gus Miftah dalam berdakwah di Lokalisasi Pasar Kembang, yakni membangun komunikasi dan kerja sama dengan preman Pasar Kembang, pemerintah setempat, dan para kepolisian, seperti yang akan peneliti paparkan.

\section{1) Membuat Kesepakatan Dengan Preman Pasar Kembang}

Negosiasi merupakan salah keterampilan yang seharusnya dimiliki oleh setiap da'i. Hal ini dikarenakan banyaknya da'i yang hanya pintar beretorika, namun lemah dalam bernegosiasi (Tommy Suprapto, 2007: 34). Hal ini sebagaimana yang dialami oleh Gus Miftah saat pertama kali berdakwah di Lokalisasi Pasar Kembang, beliau banyak mendapat teror dan ancaman dari preman yang berada di Lokalisasi Pasar Kembang. Untuk mengatasi hal tersebut, Gus Miftah melakukan negosiasi dengan dengan preman-preman yang ada di Lokalisasi Pasar Kembang. Pada mulanya Gus Miftah meminta kesempatan untuk bernegosiasi dengan preman-preman tersebut. Setelah melakukan negosiasi, maka dicapailah kesepakatan, bahwa Gus Miftah diperbolehkan berdakwah di Lokalisasi Pasar Kembang dengan syarat jangan berbuat yang macam-macam di tempat tersebut.

Jadi, dalam menghadapi tantangan dakwah tidak semudah membalikkan telapak tangan, dibutuhkan perjuangan, pengorbanan dan kesabaran dalam mewujudkan misi dakwah. Keterampilan negosiasi sangat dibutuhkan oleh da'i. Melalui negosiasi, seorang da'i dapat membangun hubungan yang akrab dengan semua pihak. Dengan demikian, dakwah yang disampaikan oleh da'i dapat diterima dengan mudah dan mendapat dukungan dari semua orang. Sebagaimana yang dirasakan oleh Gus Miftah, beliau berhasil meyakinkan dan melakukan negosiasi dengan preman, sehingga beliau mendapat dukungan dari semua pihak (preman, mucikari, dan PSK dan lainnya). 
2) Kerja Sama Dengan Kelurahan Sosromenduran

Dalam dunia dakwah, sebagian besar kesuksesan seorang da'i dalam menyampaikan dakwah tidak lepas dari andil kekuasaan. Kekuasaan merupakan benteng yang paling urgen dalam penyebaran ajaran Islam. Dengan kekuasaan, jalan dan peluang dakwah akan lebih terbuka luas untuk menegakkan dan menyebarkan Islam secara menyeluruh. Selain itu, kekuasaan juga dapat merubah yang hak dan yang batil, sebab kekuasaan menjadi salah satu sarana penting untuk mencapai sukses dan gagalnya suatu dakwah. Sebagaimana Rasulullah SAW bersabda.

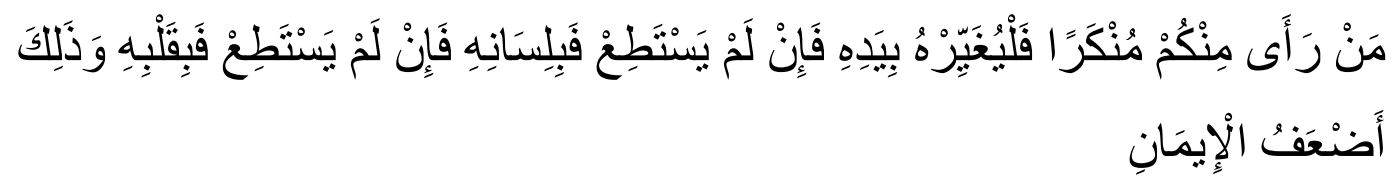

Artinya: barang siapa di antara kamu melihat kemungkaran, hendaklah ia mencegah kemungkaran itu dengan tangannya. Jika tidak mampu, hendaklah mencegahnya dengan lisan, jika tidak mampu juga, hendaklah ia mencegahnya dengan hati, itulah selemah-lemah iman $(H$. R. Muslim).

Begitu juga aktivitas dakwah yang dilakukan oleh Gus Miftah di Lokalisasi Pasar Kembang Yogyakarta. Kegiatan dakwah yang dilakukan oleh Gus Miftah terbilang sukses dan berhasil, karena adanya dukungan dan andil dari pemerintah setempat. Kunci suksesnya dakwah yang dilakukan oleh Gus Miftah di Lokalisasi Pasar Kembang adalah karena beliau mampu membangun pendekatan komunikasi dakwah secara emosional dengan pejabat setempat, yakni kelurahan Sosromenduran dan ketua RW 03 kampung Sosrowiyan Kulon. Dengan membangun pendekatan dakwah secara emosional, peluang dan kesempatan berdakwah sangat terbuka luas.

Setelah melakukan pendekatan secara emosional, pihak kelurahan Sosromenduran memberikan fasilitas tempat yang digunakan untuk 
menyampaikan dakwah di Lokalisasi Pasar Kembang. Tempat yang digunakan tersebut adalah balai RW 03 Kampung Sosrowijayan Kulon, termasuk fasilitas lainnya seperti sound system, dan menyiapkan wireless sebagai cadangan jika listrik tiba-tiba mati.

\section{3) Kerja Sama Dengan Kepolisian}

Berdakwah di Lokalisasi bukanlah suatu pilihan yang mudah, karena banyak aspek yang perlu dipertimbangkan, terutama aspek keamanan. Oleh karena itu, Gus Miftah dalam berdakwah di Lokalisasi Pasar Kembang melakukan pendekatan audiensi dengan aparat setempat. Dalam hal ini, Gus Miftah membangun komunikasi dengan Polsek Gedongtengen.

Sebagai pendakwah di Lokalisasi, keamanan sangat diperlukan untuk menjaga kesalamatan diri da'i. Sebagai ikhtiar, seorang da'i sangat membutuhkan dukungan dari pihak kepolisan. Selain itu, Gus Miftah juga mendapat dukungan dari tokoh masyarakat, dan tokoh agama. Dengan mendapat support dan dukungan dari pihak aparat, tokoh masyarakat, tokoh agama dan ulama, tentu akan menjadi satu power dan semangat dalam menyampaikan misi dakwah serta akan meminimalisir gangguan dari orang-orang yang tidak senang dengan dakwah Gus Miftah.

\section{d. Pemilihan Materi Yang Cocok}

Seorang da'i harus mampu menyajikan materi yang disampaikan dengan mudah, ringan dan diolah dengan semenarik mungkin agar mudah dipahami dan diterima oleh mad'u.

Berdakwah di Lokalisasi Pasar Kembang, Gus Miftah selain memperhatikan keadaan mad'u juga memikirkan bagaimana materi dakwah yang disampaikan dapat dipahami oleh mereka. Gus Miftah harus mendesain materi dakwah itu dengan ringan, artinya beliau harus memberikan pesan dakwah yang mudah ditangkap oleh akal fikiran mereka. Adapun strategi pengemasan materi dakwah yang dilakukan oleh Gus Miftah adalah sebagai berikut. 


\section{1) Materi Yang Memotivasi}

Materi yang memotivasi maksudnya adalah menyampaikan pesan dakwah dengan menyisipkan kisah Rasulullah SAW, sahabat-sahabat Rasulullah, Wali Songo dan yang lainnya yang bertujuan untuk membangkitkan spirit keagamaan dan keberagaman mereka. Kisah inspirasi ini perlu disampaikan kepada mereka sebagai penggugah jiwa bahwa Rasulullah, sahabat dan Wali Songo dalam berdakwah juga mendapat tantangan, rintangan, cobaan, ejekan bahkan sampai kepada pembunuhan. Gus Miftah memotivasi mereka dengan mengambil hikmah dari kisah inspirasi tersebut.

Selain itu, Gus Miftah juga memotivasi mereka dengan mengisahkan seorang pezina yang menjadi penghuni surga. Dimana pezina tersebut selalu meninggalkan apa yang diperintahkan oleh Allah dan bahkan melakukan apa dilarang oleh Allah. Namun, karena kegigihannya untuk bertaubat kepada Allah SWT dan mencari ampunan Allah maka pezina tersebut diampuni oleh Allah bahkan menjadi salah satu penghuni surga. Gus Miftah menjelaskan qulya 'ibadi bahwa Allah mengatakan katakanlah hambaku yang melampai batas, bukan mengatakan wahai hambaku yang bermaksiat dan hambaku pendosa.

"Maka saya mengatakan begini kepada mereka, cukup tubuhmu saja yang bermaksiat, tapi jangan hatimu ikut bermaksiat" (wawancara dengan Gus Miftah selaku pendiri Pondok Pesantren Ora Aji, 1 Juli 2020).

Dalam menyampaikan dakwah di Lokalisasi Pasar Kembang, Gus Miftah memberikan kemasan materi yang berisikan motivasi dan memberikan optimisme kepada mereka bukan dengan pesimisme. Karena, betapa berat perjuangan mereka untuk menemukan jalan kepada Tuhannya, tapi seolah-olah jalan itu tertutup dengan orang-orang yang menganggap dirinya lebih baik, maka perlu memotivasi mereka, membakar semangat mereka agar konsisten pada kebaikan.

"Saya katakan begini mas, kepada mereka, pada akhirnya surga itu akan ditempati oleh ahli maksiat yang pada akhirnya bertobat, bukan orang yang sok suci pada akhirnya tersesat, lebih baik orang bermaksiat tapi 
khawatir dengan maksiatnya, daripada orang yang banyak amalan tapi sombong dengan amalannya" (wawancara dengan Gus Miftah selaku pendiri Pondok Pesantren Ora Aji, 1 Juli 2020).

Gus Miftah dalam berdakwah di Lokalisasi Pasar Kembang menggunakan materi dakwah yang memotivasi, yakni memotivasi mereka dengan kisah perjuangan Rasulullah, Wali Songo dan sahabat Rasulullah lainnya. Dengan pendekatan dakwah melalui kisah motivasi tersebut, Gus Miftah dapat menumbuhkan dan menanamkan sikap optimis, percaya diri, agar tetap selalu istiqomah di pada jalan Allah SWT.

\section{2) Materi Yang Mendamaikan}

Materi yang mendamaikan adalah menyampaikan dakwah dengan materi yang menyatukan, menyejukkan, dan membawa perdamaian bukan dengan materi yang memecah belah persatuan. Artinya pesan dakwah yang disampaikan oleh da'i, mengandung nilai-nilai kebaikan, bukan nilai-nilai yang mengarah pada ujaran kebencian, apalagi sampai memecah belah wathoniyyah, insaniyah dan ukhuwah Islamiyah.

Menurut Abdul Basit, dalam bukunya yang berjudul "filsafat dakwah" menjelaskan bahwa untuk membedakan materi dakwah dengan yang lain, perlu mengenal karakteristik materi dakwah. Karakteristik materi dakwah yaitu Mengandung unsur kebenaran, Tidak bertentangan dengan nilai-nilai universal, Mengapresiasi adanya perbedaan dan toleransi. (Abdul Basit, 2013: 142).

Dakwah merupakan mengajak manusia kepada kebaikan, yang bertujuan untuk merangkul keberagaman. Namun, akhir-akhir ini banyak da'i yang membawa materi dakwah yang meresahkan masyarakat, mengatakan kelompok dia yang paling benar, kelompok yang itu salah, mereka mudah membid'ahkan bahkan mudah untuk mengkafirkan orang lain. Materi yang dibawa semacam ini, akan mempengaruhi umat untuk mudah membenci, serta berpotensi memecah 
belah persatuan umat.

Dalam berdakwah, seorang da'i harus merangkul semua tanpa melihat latar belakang suku, agama dan ras. Sebagaimana yang dilakukan oleh Gus Miftah berdakwah di Lokalisasi Pasar Kembang. Tidak semua penghuni Lokalisasi Pasar Kembang berasal dari Yogyakarta tapi juga berasal dari luar daerah Yogyakarta. Keberagaman inilah yang dimanfaatkan oleh Gus Miftah sebagai peluang dakwah, sebab dakwah yang dilakukan dalam posisi seperti ini biasanya akan mudah diterima, bila materi yang disampaikan mendamaikan dan merangkul.

Salah satu kesuksesan dakwah Gus Miftah di Lokalisasi Pasar Kembang adalah tidak pernah sekalipun melontarkan kata-kata untuk memvonis dan menghakimi mereka (PSK, mucikari dan preman) dengan pekerjaan yang mereka jalani. Konten dakwah yang disampaikan pun berisi pesan dakwah yang toleran.

3) Materi Yang Variatif

Materi yang variatif adalah mengelolah materi yang disampaikan bervariasi, beragam dan relevan, bukan dengan materi yang monoton dan membosankan. Pemilihan materi yang variatif merupakan salah satu faktor yang menjadi daya tarik bagi mad'u. Suatu materi dikatakan variatif apabila menggunakan tema-tema yang beragam. Dalam berdakwah, menyampaikan materi itu mudah, tetapi menentukan dan mengolah materi yang cocok dengan kebutuhan mad'u itu bukanlah pekerjaan yang mudah. Seorang da'i harus mengetahui materi yang relevan dengan mad'u, pemilihan kata yang mudah dimengerti, dan materi yang dapat membangkitkan semangat untuk mendengar.

Sebagaimana dakwah yang dilakukan oleh Gus Miftah di Lokalisasi Pasar Kembang. Materi dakwah yang digunakan Gus Miftah bervariasi dan tidak monoton. Salah satu yang dilakukan oleh beliau adalah dengan memberikan materi yang bersifat umum, artinya materi yang dapat diterima oleh mereka semua. Dalam hal ini, materi yang disampaikan Gus Miftah setiap bulannya berubah-rubah dan disesuaikan dengan keadaan mereka. 
Selain itu, Gus Miftah juga tidak hanya terfokus pada satu pembahasan materi, namun juga pembahasan lain yang aktual yang dapat memberikan efek dan solusi dengan problem yang mereka hadapi. Gus Miftah menjelaskan bahwa siapa yang berani hidup maka dia juga harus siap untuk berhadapan dengan masalah. Masalah manusia bermacam-macam, mulai dari masalah ekonomi, sosial, keluarga, saudara, teman, bahkan sampai pada permasalahan percintaaan (kekasih), itu masalah yang pasti manusia hadapi. Dengan demikian, melalui materi yang variative diharapkan menjadi daya tarik bagi mereka, sehingga mereka mudah menerima dakwah yan disampaikan

\section{e. Metode Yang Efektif}

Metode dakwah merupakan salah satu strategi penyampaian materi dakwah kepada mad'u yang dirancang dan dipersiapkan saat seorang da'i melakukan aktivitas dakwah. Sebagus dan secantik apapun materi yang disampaikan oleh seorang da'i, jika metode penyampaiannya tidak bagus maka dakwah yang disampaikan banyak berpotensi gagal. Sebaliknya sejelek apapun persiapan materi dakwah yang hendak disampaikan, jika cara penyampainnya bagus, maka materi dakwah akan mudah diterima. Sebagaimana petuah orang Arab mengatakan; "Atthariqoh ahammu minal maddah" metode atau teknik lebih penting daripada materinya.

Dalam berdakwah di Lokalisasi Pasar Kembang, Gus Miftah menggunakan metode dakwah jemput bola, namun beliau juga seperti para da'i pada umumnya tetap menerapkan metode dakwah yang ada di Surat An-Nahl ayat 125, hanya saja yang menjadi pembeda dan terbilang unik, Gus Miftah menggunakan metode dakwah jemput bola.

Gus Miftah menggunakan metode bil hikmah untuk menyampaikan materi dakwah atau kebenaran dengan bobot konten yang pas sesuai dengan kondisi mereka, disampaikan secara bertahap mulai dari yang mudah sampai hal yang 
sulit. Sesuai dengan pesan Rasulullah SAW, yassiru wala tu'assiru, mudahkan jangan mempersulit. Dalam menyampaikan materi dakwah, Allah pun selalu mendahulukan kabar gembira.

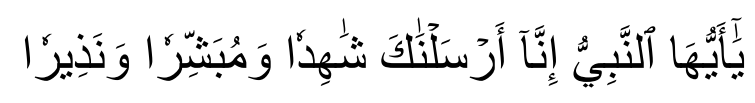

Artinya: Hai Nabi, sesungguhnya Kami mengutusmu untuk jadi saksi, dan pembawa kabar gemgira dan pemberi peringatan. (Q.S. Al-Ahzab: 45).

Dari ayat tersebut, Gus Miftah memahami, bahwa kabar gembira harus dominan daripada peringatan, sebab jika dihitung sifat Allah yang maha pengampun jauh lebih banyak dari sifat Allah yang mengandung makna peringatan. Hal inilah yang diterapkan Gus Miftah di Lokalisasi Pasar Kembang, yakni caranya tidak mendahulukan ancaman dan menakut-nakuti mereka, tapi beliau mendahulukan kabar gembira seperti mennyampaikan sifat Allah yang maha pengampun. Sebagaimana penuturan Gus Miftah.

"Begini Mas, kalau kita banyak menyampaikan pesan dakwah tentang azab Allah, pedihnya hukuman, kerasnya siksa Allah, ketimbang dari kemaha ampunan Allah, kemaha murahan Allah, maka bisa dipastikan mereka akan beranggapan bahwa Islam itu sulit, dan Allah itu suka menghukum. Kalau hal semacam ini yang dibuat di Sarkem, mereka bukannya mendekat, malah menjauh dari Islam. Sebab itu kanjeng Nabi berpesan, bassyiru walatunaffiru, kanjeng nabi mengatakan, berikan kabar gembira, jangan membuat mereka lari. Berikan materi yang ringan jangan menyulitkan mereka".

Sedangkan mau'izotil hasanah, Gus Miftah gunakan dengan cara memberikan nasehat yang baik yang bisa diterima baik oleh mereka, dengan tutur sapa yang sopan dan lembut tanpa ada unsur pemaksaan didalamnya. Dalam menerapkan metode ini, Gus Miftah harus mengetahui kondisi mad'u sebelumnya. Dengan mengetahui hal tersebut, beliau akan leluasa dalam menyampaikan materi dakwah. Jadi, dalam berdakwah di Lokalisasi Pasar 
Kembang, Gus Miftah menggunakan metode bil hikmah dan mau'izotil hasanah dan juga pendekatan-pendekatan dakwah lainnya.

\section{f. Penyampaian Dakwah Yang Menarik}

Penyampaian dakwah yang menarik merupakan poin penting yang menentukan keberhasilan suatu dakwah. Sebaik apapun materi yang disiapkan, tapi jika penyampaiannya tidak menarik maka hasilnya kurang maksimal. Oleh karena itu, untuk mendapatkan hasil dakwah yang maksimal diperlukan materi yang bagus serta penyampaian yang menarik. Penyampaikan dakwah yang menarik yaitu menyampaikan pesan dakwah dengan menggunakan teknik yang kreatif.

Salah satu penyampaian dakwah yang dipakai oleh Gus Miftah di Pasar Kembang adalah dengan menggunakan retorika. Retorika adalah seni berbicara atau seni penyampaian dakwah dengan keterampilan berbahasa yang efektif (Anwar Arifin, 2011: 261). Menurut Aristoteles, seorang da'i harus memiliki ethos yaitu faktor persona (kredibilitas da'i), dimana kepribadian da'i jauh lebih penting dari pesan yang disampaikan. Phatos yaitu dimensi yang menyentuh emosi dalam retorika, sedang logos yaitu dimensi yang bekaitan dengan penggunaan argumentasi yang masukn akal (logis) dan fakta-fakta yang nyata. Jadi, ethos, pathos, dan logos sangat berkaitan dengan keilmuan atau kepakaran seorang da'i dalam bidang agama Islam, karena keilmuaan da'i tergabung semua unsur yaitu karakter, kematangan emosi dan kemantapan ilmu (Anwar Arifin, 2011: 265).

Jadi, semua unsur tersebut haruslah ada pada diri seorang da'i. Selain unsur tersebut juga seorang da'i memerhatikan kondisi mad'u sebagai sasaran dakwahnya. Retorika merupakan teknik yang paling banyak digunakan oleh para da'i. Dalam menyampaikan pesan dakwah, Gus Miftah memulainya dengan stand up comedy. Hal ini bertujan untuk mencairkan suasana dan mengurangi 
ketegangan mad'u (PSK, mucikari dan preman). Dengan demikian, sesulit apapun pintu masuk dakwah jika sudah diawali dengan keakraban maka dakwah akan lebih mudah diterima.

Pesan dakwah yang disampaikan oleh Gus Miftah juga memperhatikan jeda dan ritme suara, kadang cepat dan kadang lambat, kadang tinggi dan kadang rendah, disesuaikan dengan keadaan mereka. Jika pesan dakwah yang disampaikan terlalu berat, maka Gus Miftah mengulangi dan menjelaskan maksud dari apa yang disampaikannya tersebut.

Dalam berdakwah, Gus Miftah juga sering kali menyisipkan humor atau lelucon yang kepada mereka. Humor yang dimaksud disini adalah humor yang berbobot atau berisi yang tidak keluar dari koridor pembahasan yang disampaikan oleh Gus Miftah. Dalam menyampaikan dakwah tersebut, Gus Miftah juga menghindari dari humor-humor yang tidak berkaitan dengan mereka, humorhumor yang tidak bermanfaat, sebab terkadang banyak da'i yang menyisipkan humor yang tidak penting, sehingga nilai esensial dakwah itu hilang. Dalam memberikan humor, berilah humor yang mengedukasi, lucu tapi memiliki nilainilai yang bagus.

Hal yang penting juga dalam menyampaian dakwah adalah bahasa. Bahasa yang digunakan disesuaikan dengan sasaran dakwah. Dalam hal ini, Gus Miftah berdakwah di Lokalisasi Pasar Kembang menggunakan bahasa Indonesia, Jawa, Arab dan juga dengan bahasa gaul. Gus Miftah menggunakan bahasa campuran bertujuan sebagai pemantik agar dakwah mudah diterima. Jadi, Gus Miftah berdakwah di Loklisasi Pasar Kembang menggunakan penyampaian yang menarik, mudah dimengerti, dan didesain sebaik mungkin supaya mereka tidak merasa jenuh, bosan, yang tentunya bertujuan untuk mengajak mereka ke jalan Allah dan dakwah mudah diterima oleh mereka. 


\section{Penutup}

Langkah strategis komunikasi dakwah yang digunakan Gus Miftah dalam berdakwah di Lokalisasi Pasar Kembang yaitu menggunakan pendekatan dakwah kultural dan struktural. Adapun langkah-langkah yang dilakukan oleh Gus Miftah dalam memujudkan agar dakwah diterima serta dalam membangun komunikasi dakwah di masyarakat Lokalisasi Pasar Kembang adalah sebagai berikut.

1. Membangun kredibilitas di mata masyarakat Pasar Kembang agar dakwah dapat diterima oleh mereka (PSK, mucikari, dan preman). Kredibilitas kepribadian seorang da'i dapat berdampak diterimanya suatu dakwah. Dengan kepribadian dan keteladanan dapat membangun kepercayaan masyarakat Lokalisasi Pasar Kembang dengan memanfaatkan karakter dan potensi yang ada pada Gus Miftah, yaitu bahwa Gus Miftah merupakan da'i yang kharismatik, ikhlas, istiqomah dan memberikan fasilitas dakwah dengan niat fastabiqul khairot.

2. Mengenal kondisi komunikan dakwah. Gus Miftah memahami karakter psikologis, sosial, ekonomi dan budaya yang ada pada mereka (PSK, mucikari dan preman) yang bertujuan agar proses penyampaian dakwah berjalan dengan lancar dan mudah diterima.

3. Membangun kerjasama agar proses dakwah semakin lancar di Lokalisasi Pasar Kembang.

4. Pemilihan materi yang cocok yaitu mendesain materi semenarik mungkin dengan membuat materi yang memotivasi, mendamaikan, dan variatif.

5. Menggunakan metode yang efektif. Dalam hal ini, Gus Miftah menerapkan metode yang efektif dengan menggunakan metode dakwah bil hikmah wa mau'zatil hasanah.

6. Penyampaian dakwah yang menarik merupakan strategi dengan dibawakan dengan santai, humor, dan tidak menimbulkan rasa kebosanan pada mereka serta tidak menyinggung perasaan mereka (PSK, mucikari dan preman). 


\section{Referensi}

Agama, Kementerian Republik Indonesia, Al-Qur'an Tajwid dan Terjemahannya, Solo: Abyan, 2016.

Ali, Moh Aziz, Ilmu Dakwah, Jakarta: Kencana Prenada Media Group, 2012.

Anwar, Arifin, Dakwah Kontemporer Sebuah Studi Komunikasi, Yogyakarta: Graha Ilmu, 2011.

Hussein Bahresi, Hadits Shahih Bukhari Muslim, Surabaya: CV. Karya Utama, 2008.

Basit, Abdul, Filsafat Dakwah, Jakarta: Rajawali Pers, 2013.

Chalik, Abdul dan Muttaqin Habibullah, Dakwah Transformatif dari Teori ke Praktik, Yogyakarta: CV. Istana Agency, 2018.

Fajar, Waryani dan Mahfud, Mokhamad, Komunikasi Islam, Yogyakarta: Galuh Patria, 2012.

Ilahi, Wahyu, Komunikasi Dakwah, Bandung: PT Remaja Rosdakarya, 2013.

Munir, Samsul, Rekontruksi Pemikiran Dakwah Islam, Jakarta: Amzah, 2008.

Morissan, Teori Komunikasi Individu Hingga Massa, Jakarta: Kencana Prenadamedia Group, 2013.

Nurudin, Ilmu Komunikasi Imiah dan Populer, Jakarta: PT. Rajagrafindo Persada, 2016.

S, Ma'arif Bambang, Komunikasi Dakwah Paradigma untuk Aksi, Bandung: Simbiosa Rekatama Media, 2010.

Suprapto, Tommy, Teknik Jitu Persuasi dan Negosiasi, Yogyakarta, Media Pressindo, 2007.

Syamsuddin, Pengantar Sosiologi Dakwah, Jakarta: Kencana, 2016.

W, Stephen Littlejohn, Teori Komunikasi, Jakarta: Salemba Humanika, 2009. 
Maryono, dan Wakhid, Musthaofa Muhammad, Menakar Efektivitas Dakwah di Lokalisasi Pasar Kembang Dengan Pendekatan Model Matematika, Jurnal Studi Agama, Universitas Islam Indonesia, Vol. 18 No. 1 Tahun 2018.

"Per 20 Juni 2014“. Penyebaran Lokalisasi di Indonesia 2014: http://www.detiknews.com. Diakses 5 Mei 2020 pukul 14.13 WIB.

Di akses dari https://www.kemkes.go.id/folder/view/full-content/structurefaq.html, pada tanggal 22 Juni 2020 pukul 21.25 WIB. 